\title{
The role of $\mathrm{BCL} 11 \mathrm{~B}$ in hematological malignancy
}

\author{
Xin Huang ${ }^{1}$, Xin Du ${ }^{1}$ and Yangqiu $\mathrm{Li}^{2,3^{*}}$
}

\begin{abstract}
The B-cell leukemia/lymphoma 11B (BCL11B) gene is a member of the BCL family which plays a crucial role in the development, proliferation, differentiation and subsequent survival of T cells. BCL11B gene alterations are related to malignant T cell transformation that occurs in hematological malignancies. Remarkably, the BCL11B gene is responsible for the regulation of the apoptotic process and cell proliferation. This review summarizes current data and knowledge concerning the alteration of BCL11B in hematological malignancies and its role as a potential target for therapies directed against $T$ cell malignancies.
\end{abstract}

Keywords: BCL11B, Altered expression, Hematological malignancy, Apoptosis, Targeted therapy

\section{Introduction}

The structure of BCL11B

\section{The $B C L 11 B$ gene}

B-cell leukemia/lymphoma 11B (BCL11B) was first described by Ed Satterwhite in 2001. The BCL11B gene is located on mouse chromosome $12(52.0 \mathrm{cM})$ and human chromosome 14 (q32.1). Murine BCL11B shows $88 \%$ identity to the human BCL11B at nucleotide level. It has been successfully demonstrated that BCL11B expression begins in the early double negative 1 (DN 1) cell stage in the thymus, and is primarily expressed in $\mathrm{T}$ cells, thymocytes and brain tissue [1]. This gene was originally referred to as RIT1 (radiation-induced tumor suppressor gene 1) because BCL11B was isolated by scanning $\gamma$-ray-induced mouse thymic lymphomas for the loss of specific chromosomal DNA [2]. BCL11B is also known as CTIP2 (COUP-TF-interacting protein 2) because it was isolated for its interaction with the orphan nuclear receptor chicken ovalbumin upstream promoter transcription factor (COUP-TF) [3]. The BCL11B gene consists of 4 exons, and two alternatively spliced transcript variants, which encode distinct isoforms possessing or lacking exon 3, have been reported (Figure 1) $[4,5]$.

\footnotetext{
* Correspondence: yangqiuli@hotmail.com

${ }^{2}$ Institute of Hematology, Medical College, Jinan University, Guangzhou

510632, China

${ }^{3}$ Key Laboratory for Regenerative Medicine of Ministry of Education, Jinan University, Guangzhou 510632, China

Full list of author information is available at the end of the article
}

\section{The BCL11B protein}

BCL11B belongs to the Kruppel-like $\mathrm{C}_{2} \mathrm{H}_{2}$ type zinc finger transcription factor family that contains $6 \mathrm{C}_{2} \mathrm{H}_{2}$ zinc fingers and proline-rich and acidic regions with 95\% identity in their zinc finger domains [4]. BCL11B encodes two different isoforms consisting of 823 and 894 aa in humans (Figure 1). These structures include DNA binding and protein interacting regions. The long exon 4 comprises the 6 zinc-finger domains, and the $2^{\text {nd }}$ and $3^{\text {rd }}$ domains are responsible for DNA binding. Apart from the DNA binding region, BCL11B possesses domains responsible for interaction with proteins and protein complexes [5].

\section{BCL11B biological functions}

The specific functions of this gene have yet to be determined. The number of BCL11B functional studies have recently been on the rise.

\section{Transcriptional regulator}

As a transcription factor, BCL11B may be a bi-functional transcriptional regulator that acts as a repressor and transactivator [6]. BCL11B interacts with COUP-TF [3] and nucleosome remodeling and histone deacetylation complex (NuRD) [7], rendering it a potent transcriptional repressor. Genes encoding the cyclin-dependent kinase inhibitors p21/Cip2/Waf1 and p57/Kip2 are transcriptionally suppressed by BCL11B $[8,9]$. BCL11B directly interacts with the P2 promoter region of HDM2, which is the human homologue of MDM2 (mouse double minute 2) and inhibits the HDM2 promoter 


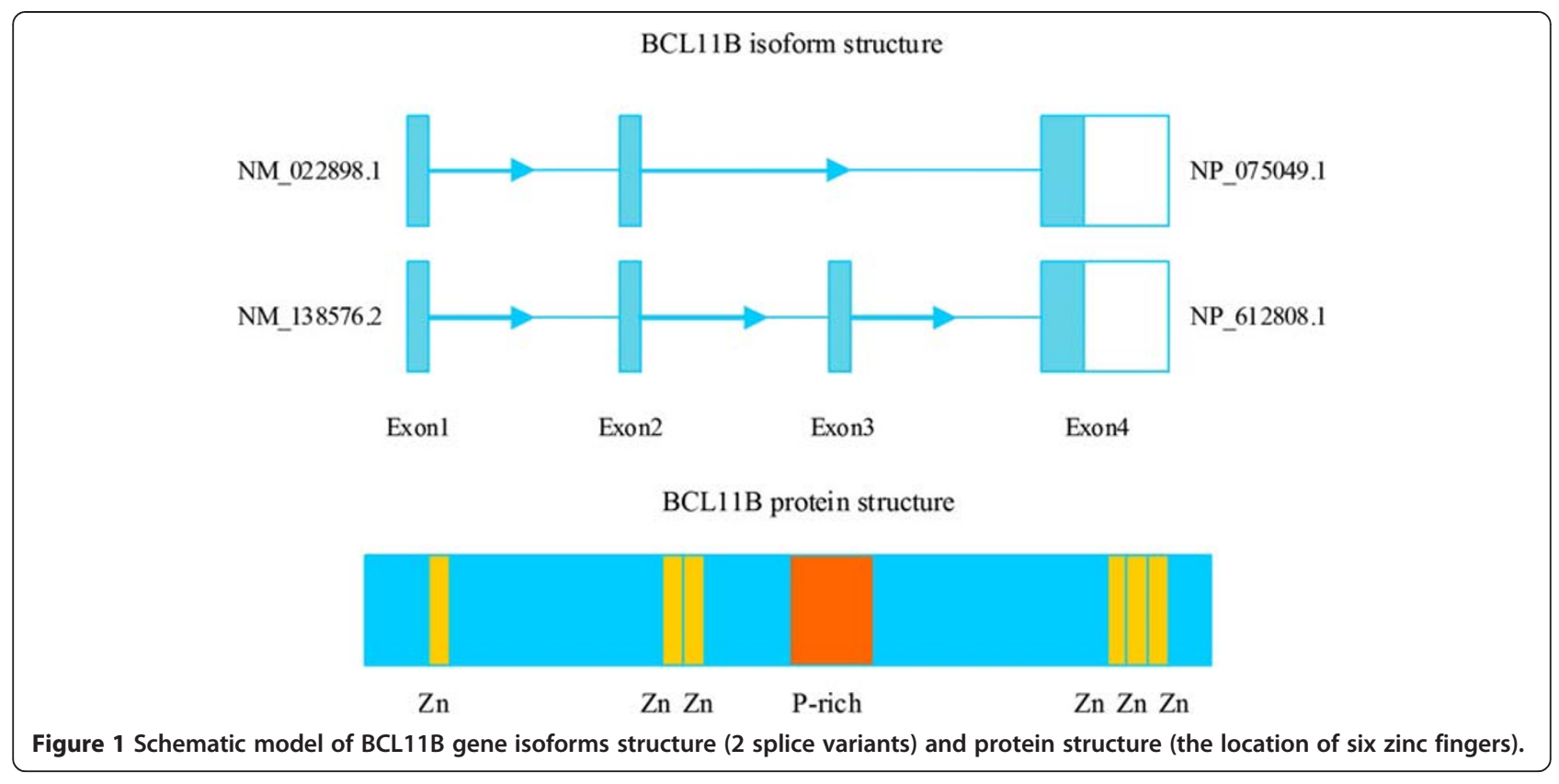

activity in a p53-dependent manner [10]. Conversely, interaction between BCL11B and the p300 coactivator at upstream site 1 (US1) in the IL-2 promoter results in transcriptional activation of IL-2 expression in activated T cells [11]. BCL11B enhances TCR/CD28-triggered NF$\mathrm{\kappa B}$ activation by up-regulating Cot kinase gene expression in T-cells [12].

T-cell development and the maintenance of T-cell identity BCL11B plays a key role in both T-cell development and subsequent maintenance of T-cell identity [13]. BCL11B is necessary for $\mathrm{T}$ lineage commitment in mice, and is specifically required in order to successfully repress natural killer cell-associated genes while down-regulating a battery of stem or progenitor cell genes at their pivotal commitment stage [6].

BCL11B-deficient mice demonstrate a block at their CD4-CD8- DN thymocytes development stage without impairment in any of the cells in the B- and $\gamma \delta$ T-cell lineages. However, Bcl11b-/- thymocytes demonstrated unsuccessful $\mathrm{V} \beta$ to $\mathrm{D} \beta$ recombination, and lacked necessary pre-T cell receptor (TCR) complex expression on the cell surface; this was due to the absence of TCR $\beta$ mRNA expression. Further, the researchers observed massive apoptosis in the thymi of neonatal BCL11B-/mice, results which indicate that $B C L 11 B$ is a key regulator of the differentiation and survival of $\alpha \beta \mathrm{T}$ cells during thymocyte development [14]. Removal of the BCL11B transcription factor in double positive (DP) thymocytes leads to an early block in invariant natural killer T-cell (iNKT) development. Remarkably, these studies demonstrated a unique, previously undescribed role played by BCL11B in DP thymocytes, in addition to its already critical function in the positive selection of conventional CD4 and CD8 single-positive thymocytes [15]. $\mathrm{T}$ cells and mature $\mathrm{T}$ cells both acquire NK cell properties, transforming them into natural killer (NK) cells upon BCL11B deletion during culture. These reprogrammed cells possess unique properties of proliferation, cytokine dependency and target cell killing $[1,16]$. Our data revealed that after $B C L 11 B$ up-regulation, naïve $T$ cells increased their proliferation ability; predominantly in the Th differentiated subset [17], which may result from increased CXCL10 and CXCL11 expression. After BCL11B down-regulation, proliferation capacity substantially decreased, which could be related to changes in expression of the mitochondrial pathway genes CFLAR, CASP8, and CASP10. Moreover, we found that BCL11B was indispensable for Treg suppressor function, the maintenance of optimal Foxp3 and IL-10 gene expression, and the induction of Foxp3 expression in conventional CD4+ T cells in response to TGF- $\beta$ and iTreg cell generation [18].

\section{Tumor suppressor}

BCL11B has recently been identified as a tumor suppressor gene $[5,19]$. It has been demonstrated that BCL11B is a haplo-insufficient tumor suppressor which collaborates with all major T-cell, acute lymphoblastic leukemia (T-ALL) oncogenic lesions during human thymocyte transformation [19], the loss of a BCL11B allele provides susceptibility to mouse thymic lymphoma [20] and human T-ALL [21-23]. The absence of a BCL11B tumor suppressor resulted in vulnerability to DNA replication stress and damage [24]. Down-regulation of the BCL11B gene by small interfering RNA (siRNA) led to growth 
inhibition and apoptosis in a human T-ALL cell line, although not in normal mature $\mathrm{T}$ and CD34+ cells [25-27].

\section{BCL11B alterations in hematological malignancies Deletion/mutation/disruption}

The findings indicated that BCL11B haplo-insufficiency occurred across each of the major T-ALL molecular subtypes, including the early T-cell precursor, HOXApositive, LEF1-inactivated, and TAL1-positive subtypes [19]. Loss-of-function BCL11B mutations contribute to mouse lymphomagenesis and thus potentially also to human cancer development [20]. Monoallelic BCL11B deletions or missense mutations were found in $9 \%(10 /$ 117) of a collection of T-ALL diagnostic specimens. There are at least six examples of intra-chromosomal interstitial BCL11B deletions caused by aberrant V (D) J recombination between non-antigen receptor loci, and five of these six are associated with lymphoid malignancy. Although the efficiency of these illegitimate V (D) J recombination events is less, by several orders of magnitude than at bonafide antigen receptor loci, such deletions result in devastating consequences, and represent a major cause of lymphoid malignancy [28]. Analysis of the D-J rearrangement at the TCR $\beta$ locus and cell surface markers after the $\gamma$-irradiation of BCL11B (KO/+) mice revealed that $\mathrm{BCL} 11 \mathrm{~B}$ allelic loss had occurred at the stage following $\mathrm{V}(\mathrm{D}) \mathrm{J}$ recombination. BCL11B heterozygosity can affect lymphomagenesis at the CD117 ${ }^{\text {high }}$ DN2 stage which occurs after the CD117 ${ }^{\text {high }}$ DN1 stage. In $\mathrm{BCL} 11 \mathrm{~B}(\mathrm{KO} /+)$ thymocytes, the expression of recognized oncogenic protein $\beta$-catenin was increased. Subsequently, the BCL11B $(\mathrm{KO} /+)$ genotype contributes to clonal expansion and differentiation arrest, which is due in part to an increase in the $\beta$-catenin level [5,29]. Structural homology modeling revealed that several of the BCL11B mutations disrupted the structure of zinc finger domains which are necessary in order for this transcription factor to bind DNA.

\section{Rearrangement/juxtaposition}

Cytogenetic studies in a patient with acute myeloid leukemia (AML) revealed that the sole karyotypic alteration of a half-cryptic rearrangement, which was identified as $\mathrm{t}(6 ; 14)$ (q25-q26; $\mathrm{q} 32)$, involved the BCL11B gene [30]. A cryptic chromosome rearrangement, $\mathrm{t}(5 ; 14)(\mathrm{q} 35.1 ; \mathrm{q} 32.2)$ was recently identified in a pediatric patient with acute lymphoblastic leukemia (ALL) [31-34], T/myeloid acute bilineal leukemia [35], and a pediatric T-ALL cell line (HPB-ALL); the rearrangement of which targets activation in HOX11L2/ TLX3 at 5q35.1 through juxtaposition with a downstream region of $\mathrm{BCL} 11 \mathrm{~B}$ at $14 \mathrm{q} 32.2$ [36]. A rearrangement of NKX2-5-BCL11B was also found in
T-cell lines PEER and CCRF-CEM, which resulted in a high level of NKX2-5 expression. NKX2-5 is a homeodomain-containing transcription factor expressed in the nucleus during embryonic development, which has been associated with T-ALL [37].

\section{Overexpression}

In the human body, BCL11B over-expression is primarily found in T-ALL $[25,26]$. A comparison of genome profiles of acute and lymphoma types revealed BCL11B over-expression in the acute form, regardless of the $14 q 32$ gain/amplification, but either low or no levels of this gene's expression in the lymphomas; these results suggest that acute and lymphoma types are genomically distinct subtypes, which thus may develop tumors via distinct genetic pathways [38]. Apoptosis resistance triggered by BCL11B over-expression was found to be accompanied by chemo-resistance caused by the accumulation of T-ALL cells in the G1 phase [39].

\section{Methylation status}

Based on a genome-wide analysis of aberrant DNA methylation in chronic lymphocytic leukemia (CLL) using methylated $\mathrm{CpG}$ island amplification (MCA), coupled with a promoter microarray, methylation status was confirmed through pyro-sequencing for 22 of these genes in 78 CLL patients, including BCL11B[40]. However, the contribution of inactivation of BCL11B in B-CLL cells requires further investigation.

\section{Targeted therapies}

Based upon funding proposal data, BCL11B targeting may be considered a new therapeutic strategy for T-cell malignancies. BCL11B silencing by RNA interference in T-ALL significantly inhibited cell proliferation and induced apoptosis. The molecular mechanism behind this result may be related to several pathways which mainly include the apoptosis pathway (e.g., TNFSF10, BIK, BNIP3, and BCL2L1 genes) and the TGF beta pathway (e.g., SPP1 and CREBBP genes) (Figure 2A) [41,42]. Global gene expression profile analysis revealed that the PHTF1 (putative homeodomain transcription factor 1) gene increased 16-fold in BCL11B siRNA-treated T-ALL cells (Figure 2B). Further, proteome analysis verified that in fact new mechanisms of BCL11B-loss driven apoptosis may be related to the mitochondrial apoptotic pathway, and observed cleavage and fragments of known caspase targets may be involved: such as myosin, spectrin, vimentin, and ERM proteins, which were up-regulated and phosphorylated upon BCL11B down-regulation. Moreover, the levels of several proteins implicated in cell cycle entry, including DUT-N, CDK6, MCM4, MCM6, and MAT1, were elevated [43]. 
(a)

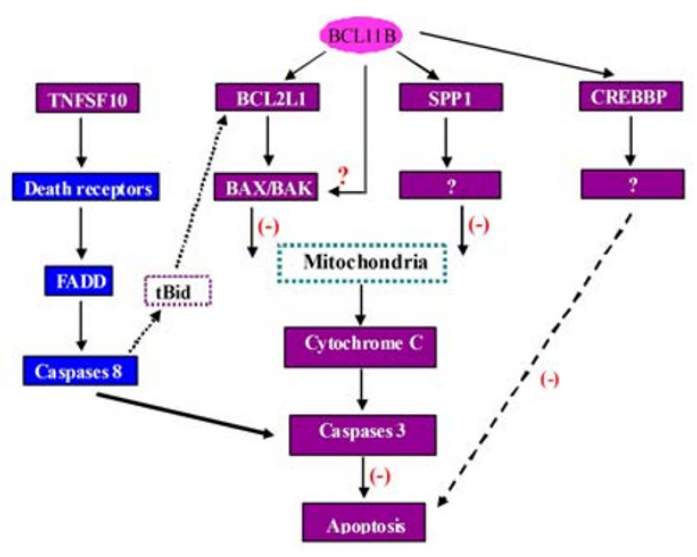

(b)

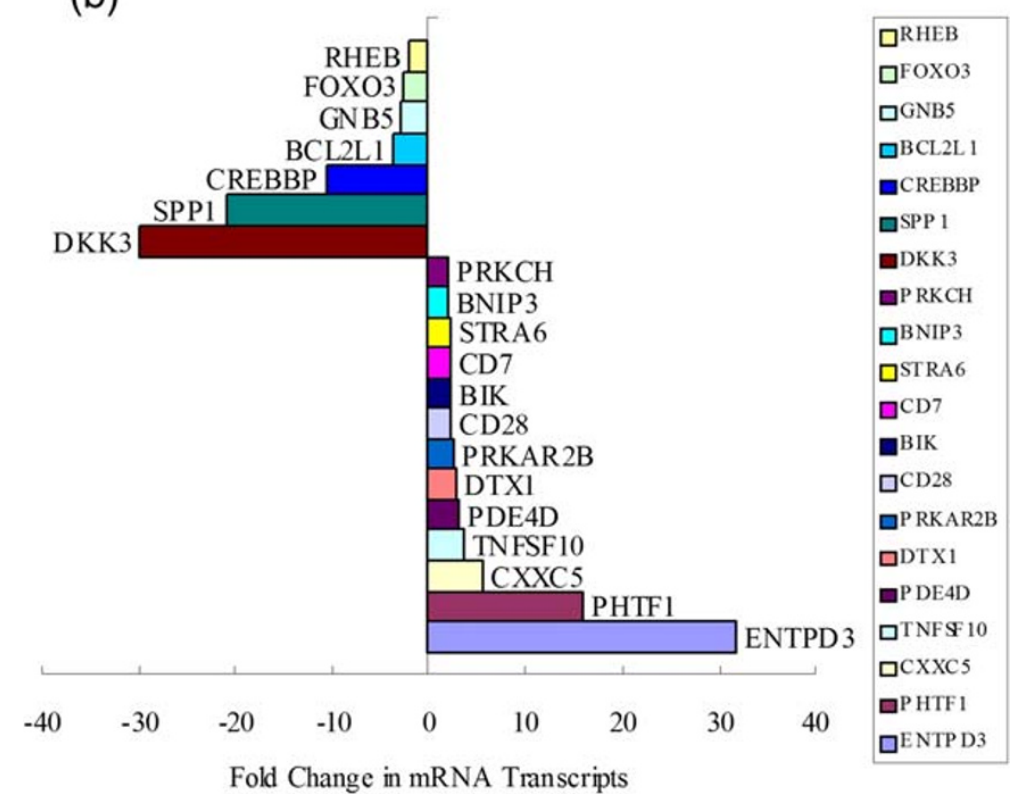

Figure 2 Schematic model of molecular mechanism of BCL11B pathways (A) and differentially expressed genes in BCL11B siRNA-treated T-ALL cells (B).

\section{Conclusions and future directions}

To improve T-cell malignancy treatment strategies, further work is necessary in order to most accurately identify therapeutic targets. Gastrointestinal stromal tumor (GIST) research and clinical care sets are examples of such translational research, capable of transforming laboratory discoveries into successful clinical applications [44]. A promising therapeutic target for T-cell malignancy therapy can indeed be the result of this fundamental, mechanistic understanding of the role of BCL11B; its regulation of the apoptotic process, and its over-expression in leukemic T cells, using a monoclonal antibody, small molecule inhibitor (or siRNA). It should be noted, however, that the inhibitory effects may be limited for single agents, and its combination with chemotherapy may have a distinctly synergistic effect in killing the leukemic cells.

\section{Competing interests}

The authors declare that they have no competing interests.

\section{Authors' contributions}

YQL directed and conceived the study and discussion. XH, XD and YQL were involved in manuscript preparation. All authors reviewed and assisted in revising the manuscript. All authors read and approved the final manuscript.

\section{Acknowledgements}

This project was sponsored by grants from the National Natural Science Foundation of China (No. 30771980, 30871091 and 81100384), the

Fundamental Research Funds for the Central Universities (No. 21610603) and the Guangdong Science \& Technology Project (No. 2007B030703008, 2009B050700029 and 2012B050600023). 


\section{Author details}

1 Department of Hematology, Guangdong General Hospital (Guangdong Academy of Medical Sciences), Guangzhou 510080, China. ${ }^{2}$ Institute of Hematology, Medical College, Jinan University, Guangzhou 510632, China ${ }^{3}$ Key Laboratory for Regenerative Medicine of Ministry of Education, Jinan University, Guangzhou 510632, China.

Received: 15 July 2012 Accepted: 8 August 2012

Published: 22 August 2012

\section{References}

1. Li P, Burke S, Wang J, Chen X, Ortiz M, Lee SC, Lu D, Campos L, Goulding D, Ng BL, Dougan G, Huntly B, Gottgens B, Jenkins NA, Copeland NG, Colucci F, Liu P: Reprogramming of T cells to natural killer-like cells upon $\mathrm{Bcl} 11 \mathrm{~b}$ deletion. Science 2010, 329:85-89.

2. Matsumoto Y, Kosugi S, Shinbo T, Chou D, Ohashi M, Wakabayashi Y, Sakai K, Okumoto M, Mori N, Aizawa S, Niwa O, Kominami R: Allelic loss analysis of $\gamma$-ray-induced mouse thymic lymphomas: two candidate tumor suppressor gene loci on chromosomes12 and 16. Oncogene 1998, 16:2747-2754

3. Avram D, Fields A: Pretty On Top K, Nevrivy DJ, Ishmael JE, Leid M: Isolation of a novel family of $\mathrm{C} 2 \mathrm{H} 2$ zinc finger proteins implicated in transcriptional repression mediated by chicken ovalbumin upstream promoter transcription factor (COUP-TF) orphan nuclear receptors. J. Biol. Chem. 2000, 275:10315-10322

4. Satterwhite E, Sonoki T, Willis TG, Harder L, Nowak R, Arriola E, Liu H, Price HP, Gesk S, Steinemann D, Schlegelberger B, Oscier DG, Siebert R, Tucker PW: Dyer Martin JS: The BCL11 gene family: involvement of BCL11A in lymphoid malignancies. Blood 2001, 98:3413-3420.

5. Ryo KOMINAMI: Role of the transcription factor Bcl11b in development and lymphomagenesis. Proc. Jpn. Acad. 2012, 88:72-87.

6. Li L, Leid M, Rothenberg EV: An Early T cell lineage commitment checkpoint dependent on the transcription factor Bcl11b. Science 2010, 329:89-93.

7. Cismasiu VB, Adamo K, Gecewicz J, Duque J, Lin Q, Avram D: BCL11B functionally associates with the NuRD complex in T lymphocytes to repress targeted promoter. Oncogene 2005, 24:6753-6764.

8. Topark-Ngarm A, Golonzhka O, Peterson VJ, Barrett B: Jr., Martinez B, Crofoot K, Filtz TM, Leid M: CTIP2 associates with the NuRD complex on the promoter of p57KIP2, a newly identified CTIP2 target gene. J. Biol. Chem. 2006, 281:32272-32283.

9. Cherrier T, Suzanne S, Redel L, Calao M, Marban C, Samah B, Mukerjee R, Schwartz C, Gras G, Sawaya BE, Zeichner SL, Aunis D, Van Lint C, Rohr O: p21WAF1 gene promoter is epigenetically silenced by CTIP2 and SUV39H1. Oncogene 2009, 28:3380-3389.

10. Obata M, Kominami R, Mishima Y: BCL11B tumor suppressor inhibits HDM2 expression in a p53-dependent manner. Cell Signal 2012, 24:1047-1052.

11. Cismasiu VB, Ghanta S, Duque J, Albu DI, Chen HM, Kasturi R, Avram D: $\mathrm{BCL} 11 \mathrm{~B}$ participates in the activation of IL2 gene expression in CD4+ $\mathrm{T}$ lymphocytes. Blood 2006, 108:2695-2702.

12. Cismasiu VB, Duque J, Paskaleva E, Califano D, Ghanta S, Young HA, Avram D: BCL11B enhances TCR/CD28-triggered NF-kappaB activation through up-regulation of Cot kinase gene expression in T-lymphocytes. Biochem J 2009, 417:1457-466.

13. LiU P, Li P, Burke S: Critical roles of Bcl11b in T-cell development and maintenance of T-cell identity. Immunol Rev 2010, 238:138-149.

14. Wakabayashi $Y$, Watanabe H, Inoue J, Takeda N, Sakata J, Mishima Y, Hitomi J, Yamamoto T, Utsuyama M, Niwa O, Aizawa S, Kominami R: Bcl11b is required for differentiation and survival of alphabeta $\mathrm{T}$ lymphocytes. Nat Immunol 2003, 4:533-539.

15. Albu DI, VanValkenburgh J, Morin N, Califano D, Jenkins NA, Copeland NG, Liu P, Avram D: Transcription factor Bcl11b controls selection of invariant natural killer T-cells by regulating glycolipid presentation in doublepositive thymocytes. Proc Natl Acad Sci U S A. 2011, 108:6211-6216.

16. Su DM, Vankayalapati R: A new avenue to cure cancer by turning adaptive immune T cells to innate immune NK cells via reprogramming. J Mol Cell Biol 2010, 2:237-239.

17. Chen S, Huang X, Chen SH, Yang LJ, Shen Q, Zheng HT, Li B, Grabarczyk P, Przybylski GK, Schmidt CA, Li YQ: The role of BCL11B in regulating the proliferation of human naive T cells. Hum Immunol 2012, 73:456-464.
18. Vanvalkenburgh J, Albu DI, Bapanpally C, Casanova S, Califano D, Jones DM, Ignatowicz L, Kawamoto S, Fagarasan S, Jenkins NA, Copeland NG, Liu P, Avram D: Critical role of Bcl11b in suppressor function of T regulatory cells and prevention of inflammatory bowel disease. J Exp Med 2011, 208:2069-2081.

19. Gutierrez A, Kentsis A, Sanda T, Holmfeldt L, Chen SC, Zhang J, Protopopov A, Chin L, Dahlberg SE, Neuberg DS, Silverman LB, Winter SS, Hunger SP, Sallan SE, Zha S, Alt FW, Downing JR, Mullighan CG, Look AT: The BCL11B tumor suppressor is mutated across the major molecular subtypes of T-cell acute lymphoblastic leukemia. Blood 2011, 118:4169-4173.

20. Wakabayashi Y, Inoue J, Takahashi Y, Matsuki A, Kosugi-Okano H, Shinbo T, Mishima Y, Niwa O, Kominami R: Homozygous deletions and point mutations of the Rit1/Bcl11b gene iny-ray induced mouse thymic lymphomas. Biochem. Biophys Res Commun 2003, 301:598-603.

21. Gutierrez A, Kentsis A, Sanda T, Holmfeldt L, Chen SC, Zhang J, Protopopov A Chin L, Dahlberg SE, Neuberg DS, Silverman LB, Winter SS: Hunger SP, Sallan SE, Zha S, Alt FW, Downing JR, Mullighan CG, Look AT: The BCL11B tumor suppressor is mutated across the major molecular subtypes of T-cell acute lymphoblastic leukemia. Blood 2001, 118:4169-4173.

22. Przybylski GK, Dik WA, Wanzeck J, Grabarczyk P, Majunke S, Martin-Subero Jl, Siebert R, Dölken G, Ludwig WD, Verhaaf B, van Dongen JJ, Schmidt CA, Langerak AW: Disruption of the BCL11B gene through inv(14) (q11.2q32.31) results in the expression of BCL11B-TRDC fusion transcripts and is associated with the absence of wild-type BCL11B transcripts in T-ALL. Leukemia 2005, 19:201-208.

23. De Keersmaecker K, Real PJ, Gatta GD, Palomero T, Sulis ML, Tosello V, Van Vlierberghe P, Barnes K, Castillo M, Sole X, Hadler M, Lenz J, Aplan PD, Kelliher M, Kee BL, Pandolfi PP, Kappes D, Gounari F, Petrie H, Van der Meulen J, Speleman F, Paietta E, Racevskis J, Wiernik PH, Rowe JM, Soulier J, Avran D, Cavé H, Dastugue N, Raimondi S, Meijerink JP, Cordon-Cardo C, Califano A, Ferrando AA: The TLX1 oncogene drives aneuploidy in T cell transformation. Nature 2010, 16:1321-1327.

24. Kamimura K, Mishima Y, Obata M, Endo T, Aoyagi Y, Kominami R: Lack of $\mathrm{Bcl11b}$ tumor suppressor results in vulnerability to DNA replication stress and damages. Oncogene 2007, 26:5840-5850.

25. Grabarczyk P, Przybylski GK, Depke M, Völker U, Bahr J, Assmus K, Bröker BM, Walther R, Schmidt CA: Inhibition of BCL11B expression leads to apoptosis of malignant but not normal mature T cells. Oncogene 2007, 26:3797-3810.

26. Huang $X$, Chen $S$, Shen $Q$, Chen SH, Yang $L$, Grabarczyk P, Przybylski GK, Schmidt CA, Li YQ: Down regulation of BCL11B expression inhibits proliferation and induces apoptosis in malignant $T$ cells by BCL11B-935-siRNA. Hematology 2011, 16:236-242.

27. Shen Q, Huang X, Chen S, Yang L, Shen SH, Li B Wu X, Grabarczyk P, Przybylski GK, Schmidt CA, Li Y: BCL11B suppression does not influence CD34 ${ }^{+}$cell differentiation and proliferation. Hematology 2012, 17: in press.

28. Onozawa M, Aplan PD: Illegitimate V(D)J recombination involving nonantigen receptor loci in lymphoid malignancy. Genes Chromosomes Cancer 2012, 51:525-535.

29. Go R, Hirose S, Morita S, Yamamoto T, Katsuragi Y, Mishima Y, Kominami R: Bcl11b heterozygosity promotes clonal expansion and differentiation arrest of thymocytes in gamma-irradiated mice. Cancer Sci 2010, 101:1347-1353.

30. Bezrookove V, van Zelderen-Bhola SL, Brink A, Szuhai K, Raap AK, Barge R, Beverstock GC, Rosenberg C: A novel t(6;14)(q25-q27;q32) in acute myelocytic leukemia involves the BCL11B gene. Cancer Genet Cytogenet 2004, 149:72-76.

31. Bernard OA, Busson-LeConiat M, Ballerini P, Mauchauffe M, Della Valle V Monni R, Nguyen Khac F, Mercher T, Penard-Lacronique V, Pasturaud P, Gressin L, Heilig R, Daniel MT, Lessard M, Berger R: A new recurrent and specific cryptic translocation, $\mathrm{t}(5 ; 14)(\mathrm{q} 35 ; \mathrm{q} 32)$, is associated with expression of the Hox11L2 gene in T acute lymphoblastic leukemia. Leukemia (Baltimore) 2001, 15:1495-1504.

32. Ballerini P, Blaise A, Busson-LeConiat M, Su XY, Zucman-Rossi J, Adam M, van den Akker J, Perot C, Pellegrino B, Landman-Parker J, Douay L, Berger R, Bernard OA: HOX11L2 expression defines a clinical subtype of pediatric T-ALL associated with poor prognosis. Blood 2002, 100:991-997.

33. Helias C, Leymarie V, Entz-Werle N, Falkenrodt A, Eyer D: Costa J A, Cherif $D$, Lutz $P$, Lessard M: Translocation $t(5 ; 14)(q 35 ; q 32)$ in three cases of childhood T cell acute lymphoblastic leukemia: a new recurring and cryptic abnormality. Leukemia 2002, 16:7-12. 
34. Su XY, Della-Valle V, Andre-Schmutz I, Lemercier C, Radford-Weiss I, Ballerini P, Lessard M, Lafage-Pochitaloff M, Mugneret F, Berger R, Romana SP, Bernard OA, Penard-Lacronique V: HOX11L2/TLX3 is transcriptionally activated through T-cell regulatory elements downstream of BCL11B as a result of the $\mathrm{t}(5 ; 14)(\mathrm{q} 35 ; \mathrm{q} 32)$. Blood 2006, 108:4198-4201.

35. Oliveira JL, Kumar R, Khan SP, Law ME, Erickson-Johnson M, Oliveira AM, Ketterling RP, Dogan A: Successful treatment of a child with $T /$ myeloid acute bilineal leukemia associated with TLX3/BCL11B fusion and $9 q$ deletion. Pediatr Blood Cancer 2011, 56:467-469.

36. Nagel S, Kaufmann M, Drexler HG, MacLeod RA: The cardiac homeobox gene NKX2-5 is deregulated by juxtaposition with BCL11B in pediatric T-ALL cell lines via a novel $t(5 ; 14)(q 35.1 ; q 32.2)$. Cancer Res 2003, 63:5329-5334.

37. Przybylski GK, Dik WA, Grabarczyk P, Wanzeck J, Chudobska P, Jankowski K, von Bergh A, van Dongen JJ, Schmidt CA, Langerak AW: The effect of a novel recombination between the homeobox gene NKX2-5 and the TRD locus in T-cell acute lymphoblastic leukemia on activation of the NKX2-5 gene. Haematologica 2006, 91:317-321.

38. Grabarczyk P, Nähse V, Delin M, Przybylski G, Depke M, Hildebrandt P, Völker $U$, Schmidt CA: Increased expression of bcl11b leads to chemoresistance accompanied by G1 accumulation. PLoS One 2010, 5:e12532.

39. Oshiro A, Tagawa H, Ohshima K, Karube K, Uike N, Tashiro Y, Utsunomiya A, Masuda M, Takasu N, Nakamura S, Morishima Y, Seto M: Identification of subtype-specific genomic alterations in aggressive adult T-cell leukemia/ lymphoma. Blood 2006, 107:4500-4507.

40. Tong WG, Wierda WG, Lin E, Kuang SQ, Bekele BN, Estrov Z, Wei Y, Yang H, Keating MJ, Garcia-Manero G: Genome-wide DNA methylation profiling of chronic lymphocytic leukemia allows identification of epigenetically repressed molecular pathways with clinical impact. Epigenetics 2010, 5:499-508.

41. Huang X, Chen SH, Shen Q, Yang L, Li B, Zhong LY, Geng SX, Du X, Li YQ: Analysis of the expression pattern of the BCL11B gene and its relatives in patients with T-cell acute lymphoblastic leukemia. $J$ Hematol Oncol 2010, 3:44.

42. Huang X, Shen Q, Chen S, Chen SH, Yang LJ, Weng JY, Du X, Grabarczyk P, Przybylski GK, Schmidt CA, Li YQ: Gene expression profiles in BCL11BsiRNA treated malignant T cells. J Hematol Oncol 2011, 4:23.

43. Karanam NK, Grabarczyk P, Hammer E, Scharf C, Venz S, Gesell-Salazar M, Barthlen W, Przybylski GK, Schmidt CA, Völker U: Proteome analysis reveals new mechanisms of Bcl11b-loss driven apoptosis. J Proteome Res 2010, 9:3799-3811.

44. Lamba G, Gupta R, Lee BY, Ambrale S, Liu DL: Current management and prognostic features for gastrointestinal stromal tumor (GIST). Exp Hematol Oncol 2012, 1:14.

doi:10.1186/2162-3619-1-22

Cite this article as: Huang et al:: The role of BCL11B in hematological malignancy. Experimental Hematology \& Oncology 2012 1:22.

\section{Submit your next manuscript to BioMed Central and take full advantage of:}

- Convenient online submission

- Thorough peer review

- No space constraints or color figure charges

- Immediate publication on acceptance

- Inclusion in PubMed, CAS, Scopus and Google Scholar

- Research which is freely available for redistribution

Submit your manuscript at www.biomedcentral.com/submit
Ciomed Central 